Florida International University FIU Digital Commons

$11-10-2010$

\title{
A survey of music educator's understanding and use of advanced audio technology in their instructional methods and strategies
}

Francesco Paolo Boccuzzi

Florida International University

DOI: $10.25148 /$ etd.FI14051176

Follow this and additional works at: https://digitalcommons.fiu.edu/etd

Part of the Music Education Commons

\section{Recommended Citation}

Boccuzzi, Francesco Paolo, "A survey of music educator's understanding and use of advanced audio technology in their instructional methods and strategies" (2010). FIU Electronic Theses and Dissertations. 1698.

https://digitalcommons.fiu.edu/etd/1698 
FLORIDA INTERNATIONAL UNIVERSITY

Miami, Florida

A SURVEY OF MUSIC EDUCATORS' UNDERSTANDING AND USE OF ADVANCED AUDIO TECHNOLOGY IN THEIR INSTRUCTIONAL METHODS

AND STRATEGIES

A thesis submitted in partial fulfillment of the requirements for the degree of

MASTER OF SCIENCE

in

MUSIC EDUCATION

by

Francesco Paolo Boccuzzi

2010 
To: Acting Dean Brian Schriner

College of Architecture and the Arts

This thesis, written by Francesco Paolo Boccuzzi, and entitled A Survey of Music Educators' Understanding and Use of Advanced Audio Technology in their Instructional Methods and Strategies, having been approved in respect to style and intellectual content, is referred to you for judgment.

We have read this thesis and recommend that it be approved.

Erskine Dottin

Janet Duguay Kirsten

Joel Galand, Major Professor

Date of Defense: November 10, 2010

The thesis of Francesco Paolo Boccuzzi is approved.

Acting Dean Brian Schriner

College of Architecture and the Arts

Interim Dean Kevin O'Shea

University Graduate School

Florida International University, 2010 


\section{DEDICATION}

This work is dedicated to the Music Teachers with all my respect. 


\section{ACKNOWLEDGMENTS}

I would like to thank all the professors at Florida International University's School of Music for their patience and their effort during the completion of this research. I would like especially to thank Dr. Joel Galand for his continued assistance, Dr. Janet Duguay Kirsten for her knowledgeable input and support. Finally, my thanks to Dr. Erskine Dottin for his high sense of professionalism, his precious guidance, and his willingness to share his knowledge and expertise with his students. 
ABSTRACT OF THE THESIS

A SURVEY OF MUSIC EDUCATORS' UNDERSTANDING AND USE OF ADVANCED AUDIO TECHNOLOGY IN THEIR INSTRUCTIONAL METHODS

AND STRATEGIES

by

Francesco Paolo Boccuzzi

Florida International University, 2010

Miami, Florida

Professor Joel Galand, Major Professor

This study examines the correlation between how certified music educators understand audio technology and how they incorporate it in their instructional methods. Participants were classroom music teachers selected from fifty middle schools in MiamiDade Public Schools. The study adopted a non-experimental research design in which a survey was the primary tool of investigation. The findings reveal that a majority of middle school music teachers in Miami-Dade are not familiar with advanced audiorecording software or any other digital device dedicated to the recording and processing of audio signals. Moreover, they report a lack of opportunities to develop this knowledge. Younger music teachers, however, are more open to developing up-to-date instructional methodologies. Most of the participants agreed that music instruction should be a platform for preparing students for a future in the entertainment industry. A basic knowledge of music business should be delivered to students enrolled in middle-school music courses. 
I. INTRODUCTION 1

Background of the Problem 3

Purpose of Study 3

Significance of Study 3

Research Questions 3

Theoretical Perspectives 4

Definition of Terms 5

Assumptions $\quad 7$

Limitations $\quad 7$

Delimitations $\quad 8$

II. LITERATURE REVIEW 9

Music Education $\quad 9$

Instructional Strategies and Methods in Music Education $\quad 10$

Instructional Technology and Music Education $\quad 15$

Current Research on How to Enhance Student Learning 17

$\begin{array}{lr}\text { III. METHODOLOGY } & 19\end{array}$

Research Design $\quad 19$

$\begin{array}{ll}\text { Population } & 19\end{array}$

Data Collection Method 19

Data Analysis Procedure $\quad 20$

$\begin{array}{ll}\text { IV. RESULTS } & 21\end{array}$

$\begin{array}{ll}\text { V. DISCUSSION/CONCLUSION } & 39\end{array}$

LIST OF REFERENCES $\quad 41$

$\begin{array}{ll}\text { APPENDIX } & 44\end{array}$ 
TABLE

PAGE

1. Demographic Data 22

2. Grade Level 22

3. Teaching Area $\quad 23$

4. Degrees Held 24

$\begin{array}{ll}\text { 5. Gender } & 24\end{array}$

$\begin{array}{ll}\text { 6. Teaching Experience } & 24\end{array}$

7. Music/Entertainment Industry Experience 25

8. Use of Computer Music-Software 25

$\begin{array}{lr}\text { 9. Publications } & 27\end{array}$

$\begin{array}{ll}\text { 10. Age } & 27\end{array}$

11. Data from Survey Questions 28

12. Correlations based on degrees earned 32

13. Correlations based on Gender 33

14. Correlations based on teaching experience 34

15. Correlations based on industry experience $\quad 35$

16. Correlations based on age 36 


\section{CHAPTER I}

\section{Introduction}

\section{Background of the Problem}

The literature is replete with calls for changes in the American educational system (Cain, 2004). Music education, like other academic subjects, is also in need of change. For example, the rapid transformations in American culture and society resulting from the increased use of electronics and other new technologies suggest a corresponding need to enhance learning in schools through the use of these new technologies. The ineffectiveness of much education in American public schools has placed "the nation at risk" in all spheres of society (Mark, 1996). In addition, it is becoming clearer that there is no way to resolve the many crises facing society (energy, economic, etc.) or for our society to be competitive in the world without continuously applying and updating technological approaches (Malerba, 2007). Therefore knowledge of new advanced technologies in every field, music included, is imperative.

Teaching today, more than in the past, should be concerned with enhancing learning. While teaching is certainly connected with the delivery of information, the transfer of knowledge, and the development of analytical and evaluative capabilities, the application of the acquired knowledge is too often overlooked. The transfer of student learning to real life is the most functional and effective aspect of teaching.

For this reason, the primary responsibility of educators is to facilitate the development and the enhancement of their students' knowledge application skills. Over the past twenty years, success in the entertainment industry's labor market has required a steadily increasing range of knowledge and skills. The entertainment industry has become 
more competitive, and its innovative uses of technology (including lasers, CDs, DVDs, electronic boards, computers, printers, and digital screens) have proven a winning formula that can serve as a model for other sectors, including education.

Leaving to the philosophers the job of analyzing whether the technological changes are positive or negative, it seems fair to conclude that there will be no return to the status quo (Lysloff \& Gay, 2003). Consequently, the longer educators wait to bring the curriculum and student learning in line with these new developments, the less effective education becomes. If the arts are the mirror of a society, then arts education must develop as well.

Advanced audio technology, in the end, is nothing more than a set of professional tools needed to update obsolete technology. These obsolete technologies include many of the music computer programs-useless for mastering and sound processing - that have been used for years in public and private school music courses. It is an exercise in futility to spend time and money using useless educational music software when actual, professional tools (advanced technology) are available and cheaper (Lipscomb, et al. 2006).

Students today are, most of the time, more aware of these modern technologies than are their teachers. This situation is not beneficial to the students. Students need a solid preparation in order to be successful in their future. Consequently, schools should prepare them to face the world armed with relevant knowledge and awareness. 


\section{Purpose of the Study}

The purpose of this study is to examine the correlation between how certified middle school music educators in Miami Dade understand audio technology and how they incorporate the latest audio technology in their instructional methods.

Significance of the Study

A study of music teachers' abilities to combine traditional instructional materials with elements of the latest music technology is important for several reasons. First, understanding relationships among different music-domains (e.g. between music compositions and the realization of the same compositions in a recording studio) can help to redirect youths' interest in the arts and the learning of music. Today's students reject the traditional role of passive learner. Practical class activities such as the planning, identifying, recording, and processing of sounds, facilitate active learning and engender opportunities for music educators to enhance students' levels of knowledge and participation.

Second, a fundamental change in pedagogical approaches may well produce better-motivated students while dispelling their perplexities about music technologies.

Third, new technology might well foster higher student-learning expectations and enhance student productivity through term-time projects that are economically affordable, easily collectible, and storable in media centers and libraries.

\section{Research Questions}

Question \#1 Are music educators acquiring knowledge about and becoming familiar with new audio-recording devices and related computer software programs?

Question \#2 Are music educators attending professional seminars and 
workshops to acquire the necessary knowledge and understanding of new audio technologies?

Question \#3 Are music educators employed in public schools delivering instruction using the latest advanced audio-recording technologies?

Question \#4 Are music educators providing their students the necessary specialized knowledge to enhance their entry in the professional entertainment industry?

Hypothesis \#1 Music educators teaching at public schools are not delivering adequate instruction in regard of new technologies useful to audio-recording.

Hypothesis \#2 Music educators are not periodically attending professional workshops and seminars enhancing their competencies regarding music technology, and music entertainment industry.

Hypothesis \#3 Music educators are not using teaching strategies in their classrooms reflecting advanced professional skills.

Hypothesis \#4 Music educators are not providing their students the necessary specialized knowledge to enhance their entry in the professional entertainment industry. Theoretical Perspectives

Learning environments using computer based-music software that is easily transferable online facilitates composing and other artistic creativity. These new teaching and learning practices open new cultural spaces to the students involved in music courses that have been revised to include them, thus helping to stimulate their overall intellectual curiosity.

Behaviorism has given way to constructivism as a dominant orientation in the theory of education and in instructional design (Burton, Moore, \& Magliaro 2007). 
Constructivism provides evidence that learners are not passive and that the learning process passes through direct experience, and direct engagement (Burton, et al. 2007).

According to Brown (1998), technology facilitates the following three elements of constructivist learning principles: self-directed learning, collaborative learning, and critical analysis. Technology facilitates a self-directed approach toward learning, allowing learners to create their own learning environment based on their particular learning style. Chat rooms, online conferences, and other computer-based venues for intellectual exchange spontaneously underline the interconnections between collaborative learning and technology.

Finally, it has been demonstrated that critical analysis, which is the most important element of constructivist learning, is enhanced by technology. The medium through which knowledge is obtained has definitively changed (Strommen \& Lincoln, 2007), and music educators should be directly involved in this gradual but irreversible process.

\section{Definition of Terms}

Advanced audio technology. The term refers to hardware and software that can be used simultaneously for industrial and educational purposes.

Analog. The term refers to all the audible matter surrounding us and perceivable by our auditory system.

Audio. Signals carried by mechanical waves through different media.

Digital. Translation into binary code $(0,1)$ of both audio and video signals. 
Epistemology. The study and theory of the cognitive and affective processes that lead to knowledge.

External Memory. External device able to record and store computerized data coming from personal computers or other digital electronic devices.

Interaction. In this context the term refers to the relationship and ability to communicate between electronic devices and users.

Interface. Technology built externally or internally to a personal computer or other digital electronic device that allows interaction between users and electronic devices.

Internal Memory. Device dedicated to data storage usually located into the central unit of a personal computer or other digital electronic devices.

Instrumental. In this context the term refers to characteristics and features belonging typically to traditional music instruments.

Laser. Technology implied in the creation and development of digital electronic devices (e.g. CDs and DVDs).

MIDI. Acronym for Musical Instrument Digital Interface. This type of technology allows electro-mechanical interactions between electronic devices (such as computers or electronic keyboards equipped with this particular interface) and musical instruments, both traditional and electronic.

Nano Technology. Latest microchip technology based on the extreme miniaturization of electronic circuits and components. Not yet completely developed, but currently considered the heart of the next computer generation.

Plug-in. In this context the term refers to virtual digital audio-processors used to manipulate audio signals. 
Quantize. Ability to codify digitally recorded audio waves using mathematical parameters.

Sequence. In this context the term refers to a succession of recorded audio events.

Vocal Booth. Soundproof room dedicated to the recording of vocal parts or acoustic instrumental performances involving the use of microphones.

Waves. In this context the term refers mainly to audio-waves.

\section{Assumptions}

Most of the problems brought to light in this study should already be the object of discussion, and possible solutions should already be forthcoming. Nonetheless, even though the integration of advanced audio technology in the music curriculum of public schools has been at the center of debates, workshops, and music teachers' professional development courses in the recent past, it seems that updating our public school music curriculum in light of these technologies has been a low priority, for reasons that remain somewhat opaque.

But it is assumed that at least the consciousness of a necessary review of instructional methods is still alive in the minds of music teachers who are aware of the rapid changes occurring in the society.

\section{Limitations}

- It was impossible to observe class performances.

- Data collection was limited to those participants who responded to the paper survey.

- Information provided by the institutions was scarce.

- Music programs were cut back in several pre-targeted middle schools. 
Delimitations

- This research has focused only on public middle schools.

- The scope of the study has been defined and limited to the County of

Miami-Dade. 


\section{CHAPTER II}

\section{Literature Review}

\section{Music Education}

For a better understanding of the present, and to gather some clues about the future of music education, it is useful to look at the history of music education. The first school law was passed in 1642 in Massachusetts. Reading and writing were the main subjects taught: music was considered, at that time, an inappropriate subject for school. Nevertheless music was included in the curriculum of the tax-supported schools that started to appear in America around 1648 (Mark, 1996).

In 1838, after more than one hundred years, Lowell Mason was able to convince the Boston School Committee (this was the name for the Board of Education at that time) to include music education in the regular curriculum of the public schools (Mark, 1996). Since then, music education has become a staple of public education throughout the country, producing excellent choruses, bands, and orchestras.

Numerous concerns remain, however, regarding how inadequately American adults are prepared for educated participation in musical events (Broudy, 1978). One reason for this outcome may be that music educators are not necessarily always aware of how their subject might be taught more effectively. Other significant limitations stem from the strict rules to which music educators are held by the educational system (L. Nemec, personal communication, September 28, 2009). Looking more deeply at the current music education profession and the research that informs it will give a clearer vision of the actual situation. 
Typically, the bachelor's degree in music is the lowest academic title required to apply for a teaching job in this field. The candidate then needs to pass several state tests within a specified time limit to acquire his or her certified status. In the meantime, the novice music instructor is already authorized to send resumes and recommendation letters to the attention of public schools principals and to set up job interviews. Subsequently, school boards, and departments of education will require most newly hired teachers to attend psychological and educational courses to complete and enhance their preparation as educators. It is difficult to believe that not a single course involving music and audio technology is required and that the few music technology workshops offered by the Florida Department of Education are not mandatory. Moreover, during the entire procedure leading to certification in music, applicants are never required to demonstrate to a qualified examiner their actual music skills and competencies.

The research literature on music education include experiments involving children who dropped out of piano lessons (e.g., Costa-Giomi, Flowers, \& Sasaki, 2005), and music educators' inability to create adequate lesson plans reflecting their students' instructional needs (Schmidt, 2005). In comparison, there is a paucity of research that focuses on music education as a useful tool to provide students a secure professional future.

Instructional Strategies and Methods in Music Education

Unlike other subjects, participating in music demands certain basic requirements of students in order for them to be functional in class. Public school music educators cannot assume that all students can sing or perform on a musical instrument. In most 
cases, they are not free to choose their students. Therefore, it is critical for them to adopt diverse teaching strategies and methods.

Though eminent musicians and researchers have introduced methodological refinements, music remains a difficult subject to teach at any grade level for several reasons. First, a natural predisposition to music involves individual innate qualities like a sense of rhythm and pitch recognition. Second, there is the need for stylistic sensitivity; knowing how to interpret passages of classical music in a manner that respects historical conventions while at the same time personalizing them is a skill that is learned gradually through immersion. Third, music requires discipline, sacrifice, and aesthetic research (Mark, 1996).

Perhaps the main pedagogical challenge, however, is to catch and hold students' attention, stimulating their interest in the subject. Over the years, many approaches have been suggested to that end. Open education, for instance was an experimental approach that gained a following among American educators in the 1970s; this methodology included exposing children to arts and music and using the child's interest as the basis of learning. Although the movement itself largely disappeared in the 1980s, many open education techniques are still in use today (Mark, 1996).

Other innovations aimed at developing effective teaching strategies and methods were introduced by American music educators who traveled overseas to investigate foreign methodologies possibly suitable to American institutions. In 1913 Placido de Monteliu, brought the Dalcroze method to the United States. Many schools adopted the Dalcroze method at that time including the Damrosch Institute of Musical Arts, later renamed the Juilliard School of Music (Mark, 1996). The Dalcroze method uses a series 
of body related exercises called eurhythmics. Students are asked to respond to rhythmical stimuli with physical motions. Other components of the Dalcroze method include ear training (solfege), and improvisation (Steiniz, 1988, cited in Mark, 1996).

Influenced by Dalcroze's dance-movement theories, the composer Carl Orff (18851982) approached music education from the idea that music should be taught in early childhood rather than in the adult years (Glasgow\& Dale, cited in Mark, 1996). Thanks to Orff, and in order to meet the practical needs of his innovative teaching ideas, new musical instruments for children were built by Klaus Becker in 1949. Carl Orff's method, called Schulwerk, has expanded in to other areas such as music therapy, producing remarkable results.

Zoltan Kodaly was another composer who contributed significantly to music education. His method was built on singing, reading and writing music, ear training, improvisation, and listening (Howard-Priscilla, 1996). The Kodaly method fosters kinesthetic development. Rhythm and melodic exercises incorporate hand signs. Kodaly discovered that hand signs help children in translating sounds and rhythms into bodily motion. Kodaly emphasized vocal over instrumental study. In the 1960s American music educators enthusiastically adopted Orff and Kodaly methods in their classrooms, often combining the two approaches and sometimes creating confusing overlaps (Mark, 1996).

In the 1950s Dr. Shinichi Suzuki brought a revolutionary method of music education to the attention of parents and teachers. Suzuki's method, "Talent Education," is focused on teaching the violin to very young children. He realized that, to some extent, children's ability to develop language skills could be applied to the learning of music (Mills and Therese, 1973). Through his personal experiences, Dr. Suzuki determined that the right 
time for the children to begin playing the violin was at age three. He aimed to make the sound and technique of the instrument familiar to the children in a manner analogous to the early acquisition of language. Dr. Suzuki’s method involves frequent listening sessions, observations, and student imitation of the teachers' progressively more complex instrumental performances.

In addition to the approaches pioneered by Dalcroze, Orff, Kodaly, and Suzuki, other methodological innovations are regularly proposed. Among these is Edwin E. Gordon's “Gordon Music Learning Theory," which provides learning and teaching strategies through "audiation" (a new approach to ear training). Professor Gordon's major contribution to music education is mostly consistent with his research about the application of psychological methodologies to the study of musical aptitude, music learning, and music development in infants and very young children.

John M. Feirabend, with his "Conversational Solfege," has found a way of enabling students to become independent musical thinkers, using a variety of folk and classical music. The method is based on breaking down famous pieces into sections and subsequently manipulating these sections to allow students to discover, understand, and appreciate the variegated aspects of musical architecture. The "Carabo-Cone Method," proposed by the violinist Madelen Carabo-Cone, envisions pre-built environments where children are allowed to learn the fundamentals of music by exploring through touch. The “Manhattanville Music Curriculum Project," developed in 1965, encourages students to create, perform, improvise, conduct, and investigate music freely within a spiral curriculum. More recently, the "Applied Groovology and Path Bands" by the American 
ethnomusicologist Dr. Charles Keil (Keil, 1993) proposes a method strongly linked with dance, rhythm, and participation.

All the innovators cited above have been essential to the development of music education, and their outstanding contributions remain influential in our classrooms, helping thousands of children to get closer to music and arts. Technology, however, has also played a fundamental role in the music instructional methodologies during the last decade. The introduction of electronic MIDI keyboards (synthesizers equipped with MIDI technology) in some music courses at elementary, middle schools, and higher academic levels has drastically changed the entire picture of music education for both teachers, and students (Muro, 1994, cited in Mark, 1996).

A MIDI keyboard is able to do many things: create accompaniments, imitate and demonstrate the voices of almost every musical instrument, generate rhythms, and much more. The potential of these new resources to enhance education and inject new vitality in music classrooms was recognized early on by some educators. Since the early 1970s, MIDI work stations have been adopted in the relatively few public schools where a music teacher had the will and the competence to set up and exploit such new devices. For years, however, the majority of music educators' attitudes toward this technological invasion has remained adverse or, at best, neutral (W. Cavington, personal communication, November 17, 2009). In the meantime, music and audio technology has continued to advance, yielding ever more powerful tools. 
According to Bunch (1992), society and technology are strictly related. Societies are defined to a considerable extent by their technological achievements. It is why anthropologists speak of the Stone Age, the Bronze Age, and the Iron Age, referring to the technology humans were able to produce and share. Even today, we identify modern societies based on their technological development. We talk about Industrial, PostIndustrial, and High-Tech Ages. It is also clear that technology and science go hand-inhand; when we talk about new scientific discoveries, we often are discussing the technological advancement of a particular scientific branch.

Thanks to continuous technological improvements, advances in audio have transformed home entertainment during the second half of the twentieth century, and this process is still ongoing (Fink, 1992). Teaching music while ignoring the helpful technology available to today's music classrooms does not make sense in an age when the entire entertainment industry relies on technology. To be sure, the use of advanced audio-technology in our public schools involves many bureaucratic and economic issues. In the past there have been some attempts to create audio-technology courses in several public schools in North Florida.

The study of music through technology in the academic environment started during the 1970s thanks to the collaboration between the Control Data Corporation, Indiana University, the University of Delaware, and the University of Illinois (Mark, 1996). The PLATO project developed by these institutions provided a network between universities through the telephone lines. Later, the invention of the microcomputer 
enhanced the possibilities for institutions and individuals to access this new technology at ever lower costs.

The first music instruction programs were developed for the Apple II computer (Muro, 1995) providing an interactive platform between computers and learners capable of adjusting automatically to different levels of instruction. The GUIDO (Graded Units for Interactive Dictation Operations), another example of CAI (Computer Assisted Instruction), was assembled at the University of Delaware. The GUIDO system, still in use, consists of a series of programs designed to improve students' ability to recognize intervals (distance between tones), harmonies, and rhythms by ear. In addition, this software contains a section dedicated to assessments in which the students can verify and keep records of their individual progress.

Further technological advancements have yielded more sophisticated systems. For example, the Yamaha program, "Music in Education" is a complete package including hardware (keyboard, mixer, remote control, and compact disk player) and software that allows the instructor to work simultaneously with the entire class or with single students. In addition, this program accommodates traditional music curricula, providing teachers the ability to use the technology in tandem with their instructional strategies and methods.

In short, from the early 1970s on, programs for listening skills, composing, ear training, music theory, instrumental methods, music appreciation, and music analysis have been produced to satisfy almost all the needs of even the most exigent music educator. But are they taken advantage of? Are they reaching public school students through the mediation of knowledgeable teachers? What are the effective goals of twenty-first-century music education? Are they limited to preparing students for 
Christmas and spring concerts or the openings of football games? How relevant is public school music education to the demand of our labor market? Students often abandon their music studies after they graduate from middle school or high school. Might they not be inspired to continue if some connections were drawn between musical skills and the entertainment industry?

The greatest obstacles sometimes come from the music educators themselves. According to the data collected in this study, there is widespread disagreement among music teachers regarding the feasibility and desirability of integrating advanced audiotechnology in the classroom. This disagreement stems in part from poor information regarding new instructional strategies and methodologies that would be especially useful to students contemplating a career in the arts and music fields.

Moreover, it seems that opportunities for music educators to enhance their knowledge about modern audio-technology are very limited. On the one hand, advanced audio technology courses, seminars, or even single classes for music teachers are offered sporadically and are not mandatory. On the other hand, the demand in the industry for trained operators and new creative forces increases daily.

\section{Current Research on How to Enhance Student Learning}

Recent studies have demonstrated that using technology can enhance student learning. Online classes and degrees are spreading globally throughout cyber space. Video-professors are becoming familiar figures.

According to epistemological studies, the real essence of knowledge is not consistent with what academic curricula require (Frasson and Gauthier, 1988). Learning how to learn does not figure in the instructional plans of the majority of the teachers. 
David Bartz and Laura Miller (1991) list twelve teaching methods that have shown a positive impact on students' learning. The article describes the following methods: (1) whole-group instruction; (2) teaching by objective; (3) adaptive or individualized instruction; (4) mastery learning; (5) cooperative learning; (6) learning styles; (7) direct instruction; (8) discovery method; (9) integrated thematic instruction; (10) peer tutoring; (11) learning by doing; (12) computer-assisted instruction.

Computer-assisted instruction (CAI), already discussed in the previous pages, was conceived in the 1980s with the advent of the microcomputers. Improved patience, consistency, and higher-order thinking skills (Roland 1990: and McCorduk and Russell 1986, cited in Bartz, 1991) are just some of the advantages attributed to CAI. 


\section{CHAPTER III}

\section{Methodology}

\section{Research Design}

This study adopts a non-experimental research design. Gathering information using a survey as the primary tool of investigation allows the immediate collection of analyzable data in the form of opinions and feedbacks. The questions addressed to professionals in the field of Music Education lead to precise answers freed from bias or vague assertions.

Finally, the inclusion in the project of the Pearson Product Moment Correlation Coefficient as an instrument of data analysis in conjunction with follow-up phone interviews with the participants confers reliability to the research in accuracy and appropriateness.

\section{Population}

Participants for this study were classroom music teachers selected from fifty middle schools in Miami- Dade County Public Schools, Districts One through Six. The population under study was representative of the ethnic, social and economic diversity of the respective areas and schools. The sample of participants comprised approximately $30 \%$ African American, 40\% Hispanic, and 30\% White/non Hispanic with 52\% females and $48 \%$ males.

\section{Data Collection Method}

Music educators were surveyed and then interviewed through follow-up questions. The researcher made notes of the answers to the follow-up questions and used the notes for further analysis. The following data were collected:

1.) Data on participants' personal characteristics (e.g., institutional information, 
education, and prior training).

2.) Information about respondents' attitudes toward changing teaching methodologies.

3.) Information regarding teachers' understanding and knowledge of the most popular professional and educational audio recording software (Cubase VST Audio, Nuendo, Protools, Logic Audio, Audio Performer, Acid, Finale, and others) available to middle-school music departments in Miami-Dade Public Schools. These programs are identified by the majority of prominent musicians and sound engineers as forming the core of the latest, advanced audio-recording technology (MacQueen, 2005).

\section{Data Analysis Procedure}

The data collected for this study were analyzed using descriptive statistics displayed in table and graphs. Inferential statistics, such as the Pearson Product Moment Correlation Coefficient, were used to make some predictions regarding the correlation between teachers' understanding of advanced audio technology and their use of the technology in their teaching methods. Survey data, information from follow-up interviews, and school curriculum documents were also major sources for this study. 


\section{CHAPTER IV}

\section{Results}

In this chapter, the data collected in this study will be analyzed, first using descriptive statistics, and then an inferential statistic, the Pearson Product Moment Correlation Coefficient, to make some predictions regarding the correlation between teachers' understanding of advanced audio technology and their use of the technology in their teaching methods. Survey data, information from follow-up interviews, and school curriculum documents are also major sources of analysis.

The study attempted to answer the following research questions:

Question \#1 Are music educators acquiring knowledge and becoming familiar with new audio-recording devices and related computer software programs?

Question \#2 Are music educators attending professional seminars and workshops to acquire the necessary knowledge and understanding of new audio technologies?

Question \#3 Are music educators employed in public schools delivering instruction using the latest advanced audio-recording technologies?

Question \#4 Are music educators providing their students the necessary specialized knowledge to enhance their entry in the professional entertainment industry?

The instrument used to collect data in this study to conduct the investigation was a survey organized in two sections. The first section was dedicated to the collection of demographic data such as work location, grade level taught, teaching area, degrees held, gender, teaching experience, music/entertainment industry experience, use of computer music software, and publications. The second section consisted of nine statements to 
which the participants were invited to give their opinion in terms of disagreement or agreement. A sample of the survey may be found in the Appendix. A complete breakdown of the results from the first section of the survey follows:

Table 1: Demographic Data

\begin{tabular}{|l|r|r|}
\hline 1 Horace Mann Middle School & 1 & 4.2 \\
2 Jose De Diego Middle School & 1 & 4.2 \\
3 Jose Martin Middle School & 1 & 4.2 \\
4 Palmetto Middle School & 1 & 4.2 \\
5 Ponce De Leon Middle School & 1 & 4.2 \\
6 South Miami Middle School & & \\
7 Southwood Middle School & 3 & 12.5 \\
8 Work Location 6361 & 3 & \\
9 Work Location 6801 & 1 & 12.5 \\
Total & 1 & 4.2 \\
10 & 13 & 4.2 \\
Total & 11 & 54.2 \\
\hline
\end{tabular}

The first column indicates the name of the schools that participated in the survey. The second column indicates the number of music teachers who completed and returned the survey to the investigator. The third column reports the percentage, by school, of participants who completed and returned the survey. Overall, $54.2 \%$ of the 24 participants returned the survey, and the $45.8 \%$ of the participants did not.

Table 2: Grade Level

$100 \%$ of the participants were teaching in grades 6,7 , and 8 . 
Table 3: Teaching Area

General Music

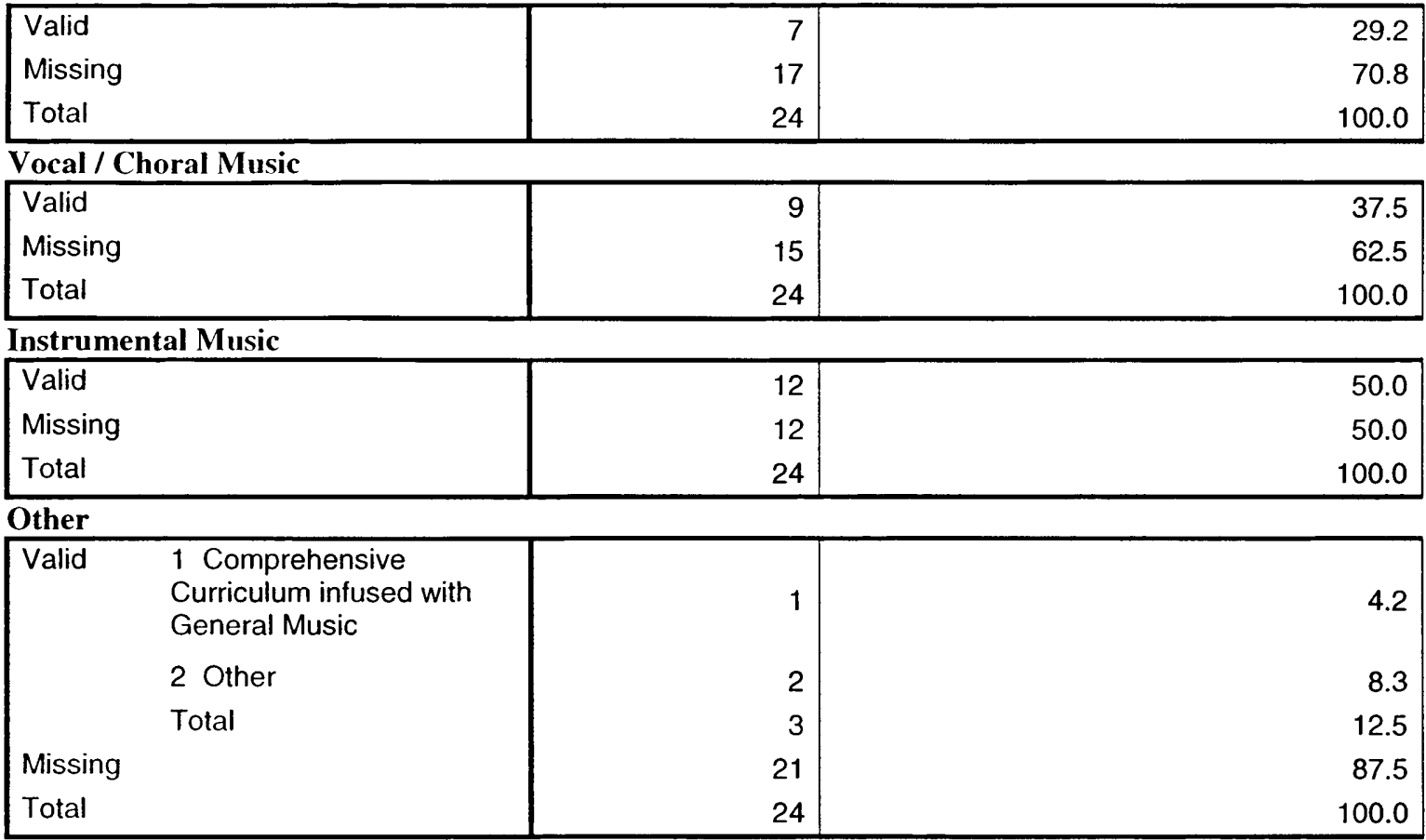

$29.2 \%$ of the participants were teaching General Music; $37.5 \%$ of the participants were teaching Vocal/Choral Music; 50\% of the participants were teaching Instrumental Music; $4.2 \%$ were teaching Comprehensive Curriculum infused with General Music, and the $8.3 \%$ were teaching other music techniques. Please notice that some participants checked more than one area of teaching, and that is why the percentages in the sub-table labeled "Other" exceed $100 \%$. 
Table 4: Degrees Held

\begin{tabular}{|l|r|r|}
\hline Bachelor's & 8 & 33.3 \\
Master's & 11 & 45.8 \\
Specialist & 1 & 4.2 \\
Doctorate & 4 & 16.7 \\
Total & 24 & 100.0 \\
\hline
\end{tabular}

$33 \%$ of the participants held a Bachelor's degree;.45\% of the participants held a

Master's degree; $4.2 \%$ held a Specialist degree; and $16.7 \%$ held a Doctorate.

Table 5: Gender

\begin{tabular}{|l|r|r|}
\hline Male & 14 & 58.3 \\
Female & 10 & 41.7 \\
Total & 24 & 100.0 \\
\hline
\end{tabular}

$58.3 \%$ of the participants were male and $41.7 \%$ female.

Table 6: Teaching Experience

1-3 years ..... 4-10 years ..... 11-20 years ..... 21-30 years ..... More than 30 years .....

\begin{tabular}{|l|r|r|}
\hline $4-10$ years & 6 & 25.0 \\
$11-20$ years & 6 & 25.0 \\
$21-30$ years & 9 & 37.5 \\
More than 30 years & 3 & 12.5 \\
Total & 24 & 100.0 \\
\hline
\end{tabular}

$50 \%$ of the participants had taught from four to twenty years, $37.5 \%$ from twenty-one to thirty years, and $12.5 \%$ of the participants for more than thirty years.

Table 7: Music/Entertainment Industry Experience

\begin{tabular}{|l|r|r|}
\hline $1-3$ years & 4 & 16.7 \\
$4-10$ years & 3 & 12.5 \\
$11-20$ years & 6 & 25.0 \\
$21-30$ years & 2 & 8.3 \\
5 More than 30 years & 3 & 12.5 \\
Total & 18 & 75.0 \\
Missing & 6 & 25.0 \\
Total & 24 & 100.0 \\
\hline
\end{tabular}


$16.7 \%$ of the participants had worked in the music entertainment industry between one and three years; $12.5 \%$ between four and ten years; $25.0 \%$ between eleven and twenty years; $8.3 \%$ between twenty-one and thirty years; $12.5 \%$ more than thirty years; and $25 \%$ of the participants did not respond to this survey item.

Table 8: Use of Computer Music-Software

Pro Tools (any version)

\begin{tabular}{|c|c|c|}
\hline Missing & 24 & 100.0 \\
\hline \multicolumn{3}{|c|}{ Cubase VST Audio (any version) } \\
\hline Valid $\quad 1$ Yes & 1 & 4.2 \\
\hline Missing & 23 & 95.8 \\
\hline Total & 24 & 100.0 \\
\hline \multicolumn{3}{|c|}{ Nuendo (any version) } \\
\hline Missing & 24 & 100.0 \\
\hline \multicolumn{3}{|c|}{ Logic Audio (any version) } \\
\hline $\begin{array}{ll}\text { Valid } 1 \text { Yes } \\
\end{array}$ & 1 & 4.2 \\
\hline Missing & 23 & 95.8 \\
\hline Total & 24 & 100.0 \\
\hline \multicolumn{3}{|c|}{ Audio Performer (any version) } \\
\hline Missing & 24 & 100.0 \\
\hline \multicolumn{3}{|c|}{ Acid (any version) } \\
\hline Valid 1 Yes & 2 & 8.3 \\
\hline Missing & 22 & 91.7 \\
\hline Total & 24 & 100.0 \\
\hline
\end{tabular}


Table 8: Use of Computer Music-Software (continued)

Finale (any version) ${ }^{*}$

\begin{tabular}{|c|c|c|}
\hline $\begin{array}{|ll|}\text { Valid } & 1 \text { Yes } \\
\text { Missing } & \\
\text { Total } & \\
\end{array}$ & $\begin{array}{r}18 \\
6 \\
24 \\
\end{array}$ & $\begin{array}{r}75 \\
25 \\
100.0 \\
\end{array}$ \\
\hline \multicolumn{3}{|c|}{ Sibelius (any version) ${ }^{*}$} \\
\hline \begin{tabular}{|lll} 
Valid & 1 Yes \\
Missing & & \\
Total & \\
\end{tabular} & $\begin{array}{r}1 \\
23 \\
24\end{array}$ & $\begin{array}{r}4.2 \\
95.8 \\
100.0\end{array}$ \\
\hline \multicolumn{3}{|c|}{ Garage Band (any version) } \\
\hline $\begin{array}{|ll|}\text { Valid } & 1 \text { Yes } \\
\text { Missing } & \\
\text { Total } & \\
\end{array}$ & $\begin{array}{r}1 \\
23 \\
24 \\
\end{array}$ & $\begin{array}{r}4.2 \\
95.8 \\
100.0 \\
\end{array}$ \\
\hline \multicolumn{3}{|c|}{ Mixcraft (any version) } \\
\hline \begin{tabular}{|ll} 
Valid & 1 Yes \\
Missing & \\
Total &
\end{tabular} & $\begin{array}{r}1 \\
23 \\
24\end{array}$ & $\begin{array}{r}4.2 \\
95.8 \\
100.0\end{array}$ \\
\hline
\end{tabular}

$100 \%$ of the participants had never used Pro Tools as a recording music software.

$4.2 \%$ of the participants used Cubase VST Audio as a recording music software. $100 \%$ of the participants had never used Nuendo as a recording music software. $4.2 \%$ of the participants used Logic Audio as a recording music software. $100 \%$ of the participants had never used Audio Performer as a recording music software. $8.3 \%$ of the participants used Acid as a recording music software. $75 \%$ of the participants used Finale as a recording music software. $4.2 \%$ of the participants used Sibelius as a recording music software. $4.2 \%$ of the participants used Garage Band as a recording music software. $4.2 \%$ of the participants used Mixcraft as a recording music software.

* Please notice that this program is basically music notation software with limited audio-recording capabilities. 
Table 9: Publications

\begin{tabular}{|ll|r|r|}
\hline Valid & Songs & 1 & 4.2 \\
& CDs & 2 & 8.3 \\
& Articles & 4 & 16.7 \\
& Books & 0 & 0 \\
& Total & 7 & 29.2 \\
Missing & & 17 & 70.8 \\
Total & & 24 & 100.0 \\
\hline
\end{tabular}

$4.2 \%$ of the participants published songs. $8.3 \%$ published a $\mathrm{CD}$ supported by major recording labels. $16.7 \%$ published articles. $70.8 \%$ of the participants did not respond to the question. $0 \%$ published books.

Table 10: Age

\begin{tabular}{|l|r|r|}
\hline $21-30$ years & 4 & 16.7 \\
$31-40$ years & 6 & 25.0 \\
$41-50$ years & 9 & 37.5 \\
$51-60$ years & 5 & 20.8 \\
61 years and older & 0 & 0 \\
Total & 24 & 100.0 \\
\hline
\end{tabular}

$16.7 \%$ of the participants were in the age range between twenty-one and thirty years old. $25.0 \%$ were between thirty-one and forty. $37.5 \%$ between forty-one and fifty. $20.8 \%$ were between fifty-one and sixty years old. $0 \%$ of the participants were sixth-one years old and older. 


\section{Table 11: Data from Survey Questions}

I fully understand the main differences existing among the latest more advanced computer music software.

\begin{tabular}{|l|r|r|}
\hline Strongly Disagree & 3 & 12.5 \\
Disagree & 11 & 45.8 \\
Neutral & 1 & 4.2 \\
Agree & 5 & 20.8 \\
Strongly Agree & 4 & 16.7 \\
Total & 24 & 100.0 \\
\hline
\end{tabular}

I have the needed knowledge and experience in regard of music industry and music business.

\begin{tabular}{|l|r|r|}
\hline Strongly Disagree & 6 & 25.0 \\
Disagree & 4 & 16.7 \\
Neutral & 6 & 25.0 \\
Agree & 4 & 16.7 \\
Strongly Agree & 4 & 16.7 \\
Total & 24 & 100.0 \\
\hline
\end{tabular}

I think it is extremely important to change teaching goals and objectives in our today's music curriculum.

\begin{tabular}{|l|r|r|}
\hline Strongly Disagree & 1 & 4.2 \\
Disagree & 5 & 20.8 \\
Neutral & 2 & 8.3 \\
Agree & 10 & 41.7 \\
Strongly Agree & 6 & 25.0 \\
Total & 24 & 100.0 \\
\hline
\end{tabular}

I would get more consideration from my students delivering advanced audio-technology culture in conjunction with the traditional instructional areas of my subject.

\begin{tabular}{|l|r|r|}
\hline Strongly Disagree & 1 & 4.2 \\
Disagree & 2 & 8.3 \\
Neutral & 4 & 16.7 \\
Agree & 9 & 37.5 \\
Strongly Agree & 8 & 33.3 \\
Total & 24 & 100.0 \\
\hline
\end{tabular}

I have the knowledge and the experience for projecting and running music laboratories equipped with advanced audio-technology.

\begin{tabular}{|l|r|r|}
\hline Strongly Disagree & 4 & 16.7 \\
Disagree & 7 & 29.2 \\
Neutral & 3 & 12.5 \\
Agree & 4 & 16.7 \\
Strongly Agree & 6 & 25.0 \\
Total & 24 & 100.0 \\
\hline
\end{tabular}




\section{Table 11: Data from Survey Questions (continued)}

It is extremely important that students understand and master basic concepts related to music and entertainment business.

\begin{tabular}{|l|r|r|}
\hline Strongly Disagree & 3 & 12.5 \\
Neutral & 5 & 20.8 \\
Agree & 8 & 33.3 \\
Strongly Agree & 8 & 33.3 \\
Total & 24 & 100.0 \\
\hline
\end{tabular}

The yearly outcomes of my students comprehend at least one CD publication within original music compositions produced entirely by my school and supported by my department and by Miami Dade Public School.

\begin{tabular}{|l|r|r|}
\hline Strongly Disagree & 10 & 41.7 \\
Disagree & 4 & 16.7 \\
Neutral & 7 & 29.2 \\
Agree & 2 & 8.3 \\
Strongly Agree & 1 & 4.2 \\
Total & 24 & 100.0 \\
\hline
\end{tabular}

I do not have difficulties finding advanced music-technology educational courses offered by Miami Dade Public Schools on a regular basis.

\begin{tabular}{|l|r|r|}
\hline Strongly Disagree & 6 & 25.0 \\
Disagree & 8 & 33.3 \\
Neutral & 6 & 25.0 \\
Agree & 3 & 12.5 \\
Strongly Agree & 1 & 4.2 \\
Total & 24 & 100.0 \\
\hline Music laboratories matching the needs of professional instruction & are present in my school. \\
\hline Strongly Disagree & 11 & 45.8 \\
Disagree & 5 & 20.8 \\
Neutral & 2 & 8.3 \\
Agree & 4 & 16.7 \\
Strongly Agree & 2 & 8.3 \\
Total & 24 & 100.0 \\
\hline
\end{tabular}

$58.3 \%$ of the participants disagreed or strongly disagreed with "I fully understand the main differences existing among the latest more advanced computer music software." $37.5 \%$ of the participants agreed or strongly agreed with the statement. $41.7 \%$ of the participants disagreed or strongly disagreed with "I have the needed knowledge and experience in regard of music industry and music business." $33.4 \%$ of the participants 
agreed or strongly agreed with the statement. $25.0 \%$ of the participants disagreed or strongly disagreed with "I think is extremely important to change teaching goals and objectives in our today's music curriculum." $66.7 \%$ of the participants agreed or strongly agreed with the statement. $12.5 \%$ of the participants disagreed or strongly disagreed with "I would get more consideration from my students delivering advanced audio-technology culture in conjunction with the traditional instructional areas of my subject." $70.8 \%$ agreed or strongly agreed with the statement. $45.9 \%$ of the participants disagreed or strongly disagreed with "I have the knowledge and the experience for projecting and running music laboratories equipped with advanced audio-technology." $41.7 \%$ agreed or strongly agreed with the statement. $12.5 \%$ of the participants strongly disagreed with "It is extremely important that students understand and master basic concepts related to music and entertainment business." $66.6 \%$ agreed or strongly agreed with the statement. $58.4 \%$ of the participants disagreed or strongly disagreed with "The yearly outcomes of my students comprehend at least one $\mathrm{CD}$ publication within original music compositions produced entirely by my school and supported by my department and by Miami Dade Public School." $12.5 \%$ agreed or strongly agreed with the statement. $58.3 \%$ of the participant disagreed or strongly disagreed with "I do not have difficulties finding advanced music-technology educational courses offered by Miami Dade Public Schools on a regular basis." $16.7 \%$ agreed or strongly agreed with the statement. $66.6 \%$ of the participants disagreed or strongly disagreed with "Music laboratories matching the needs of professional instruction are present in my school." $25.0 \%$ agreed or strongly agreed with the statement. 


\section{Follow-up Questions}

The participants were contacted and asked to answer the following four questions:

1. How did you acquire that knowledge?

2. Could you share with me any courses you took to acquire knowledge in Miami Dade Public Schools system workshops or seminars?

3. Have you recently used in your delivery of music instruction the latest advanced audio-recording technology?

4. How did you interpret the verb comprehend?

Out of 30 phone calls, it was possible to collect 12 responses from the participants. To the first question, $75 \%$ of the respondents stated that they barely knew about advanced audio-recording technology and that they never participated or were required to participate in any courses, workshops, or seminars related to this matter.

The remained $25 \%$ responded by asserting that they were knowledgeable about advanced audio-recording technology acquiring information from specialized music journals and magazines.

To the second question, the majority of the participants, did not take any course or participate in any workshop offered by Miami Dade Public Schools System regarding advanced audio-recording technology.

To the third question, $60 \%$ responded that they have often used MIDI technology to demonstrate and/or facilitate some concepts related to music theory or to the classification of musical instruments. They all stated that have never used computer software or other professional audio-recording devices in their classrooms. Forty percent of the participants stated that they sometimes recorded student performances using non- 
professional video cameras or old tape recorders. Some of them added they had stopped

audio-recording because of the poor results obtained.

Almost all of the participants responding to the last question gave to the verb to

comprehend the meaning of "to include" and "to understand," depending on the context.

Table 12: Correlations based on degrees earned

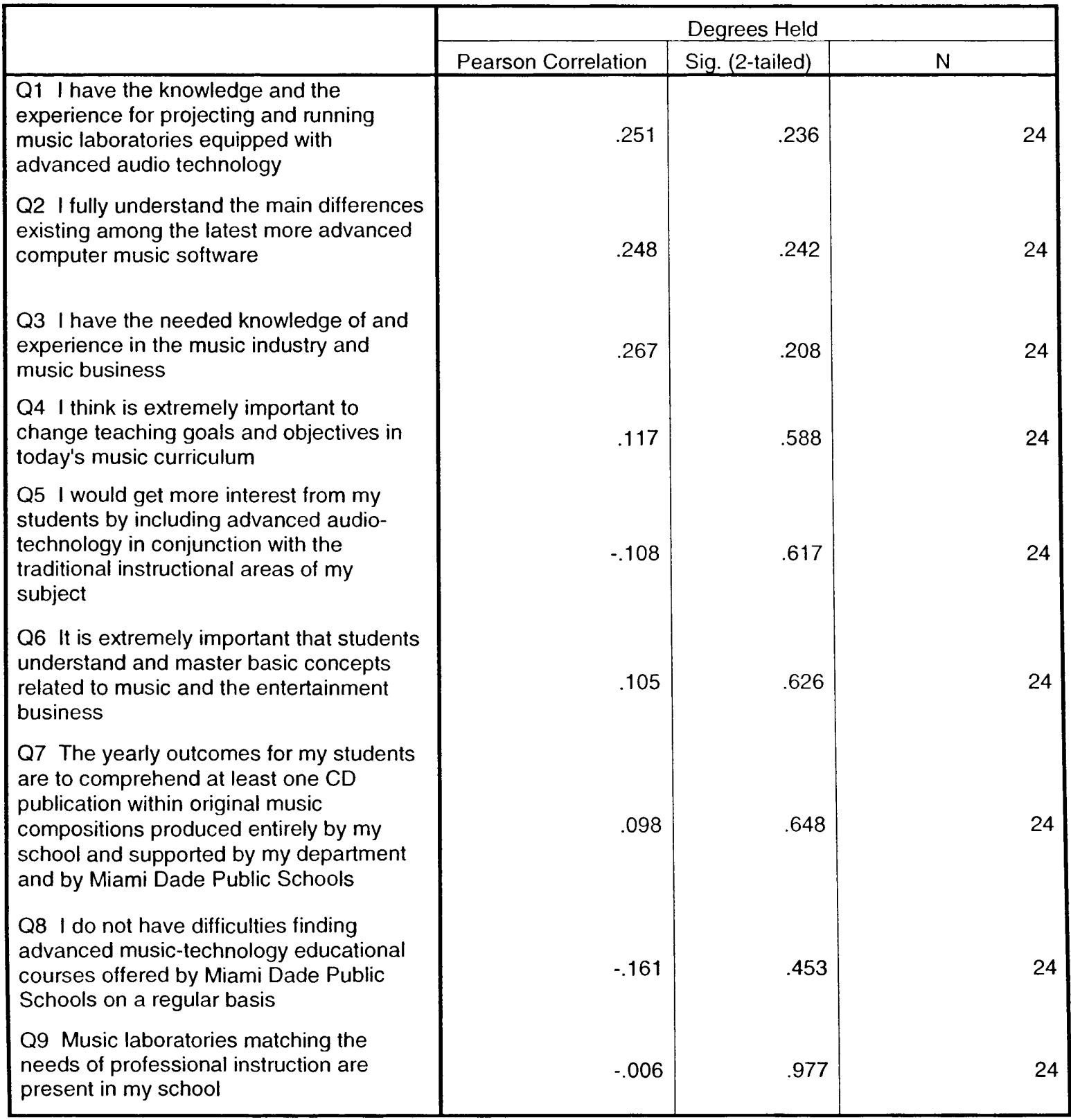

No significant correlation was found between degrees held and responses to the survey. 
Table 13: Correlations based on Gender

\begin{tabular}{|c|c|c|c|}
\hline & \multicolumn{3}{|c|}{ Gender - 1 Male 2 Female } \\
\hline & Pearson Correlation & Sig. (2-tailed) & $\mathrm{N}$ \\
\hline $\begin{array}{l}\text { Q1 I have the knowledge and the experience for } \\
\text { projecting and running music laboratories equipped } \\
\text { with advanced audio technology }\end{array}$ & -.256 & .227 & 24 \\
\hline $\begin{array}{l}\text { Q2 I fully understand the main differences existing } \\
\text { among the latest more advanced computer music } \\
\text { software }\end{array}$ & -.273 & .198 & 24 \\
\hline $\begin{array}{l}\text { Q3 I have the needed knowledge of and experience } \\
\text { in the music industry and music business }\end{array}$ & -.261 & .218 & 24 \\
\hline $\begin{array}{l}\text { Q4 I think is extremely important to change teaching } \\
\text { goals and objectives in today's music curriculum }\end{array}$ & -.089 & .678 & 24 \\
\hline $\begin{array}{l}\text { Q5 I would get more interest from my students by } \\
\text { including advanced audio-technology in conjunction } \\
\text { with the traditional instructional areas of my subject }\end{array}$ & -.058 & .788 & 24 \\
\hline $\begin{array}{l}\text { Q6 It is extremely important that students } \\
\text { understand and master basic concepts related to } \\
\text { music and the entertainment business }\end{array}$ & -.033 & .877 & 24 \\
\hline $\begin{array}{l}\text { Q7 The yearly outcomes for my students are to } \\
\text { comprehend at least one CD publication within } \\
\text { original music compositions produced entirely by my } \\
\text { school and supported by my department and by } \\
\text { Miami Dade Public Schools }\end{array}$ & -.048 & .824 & 24 \\
\hline $\begin{array}{l}\text { Q8 I do not have difficulties finding advanced music- } \\
\text { technology educational courses offered by Miami } \\
\text { Dade Public Schools on a regular basis }\end{array}$ & .171 & .424 & 24 \\
\hline $\begin{array}{l}\text { Q9 Music laboratories matching the needs of } \\
\text { professional instruction are present in my school }\end{array}$ & -.188 & .378 & 24 \\
\hline
\end{tabular}

No significant correlation was found between Gender and response to the survey questions. 
Table 14: Correlations based on teaching experience

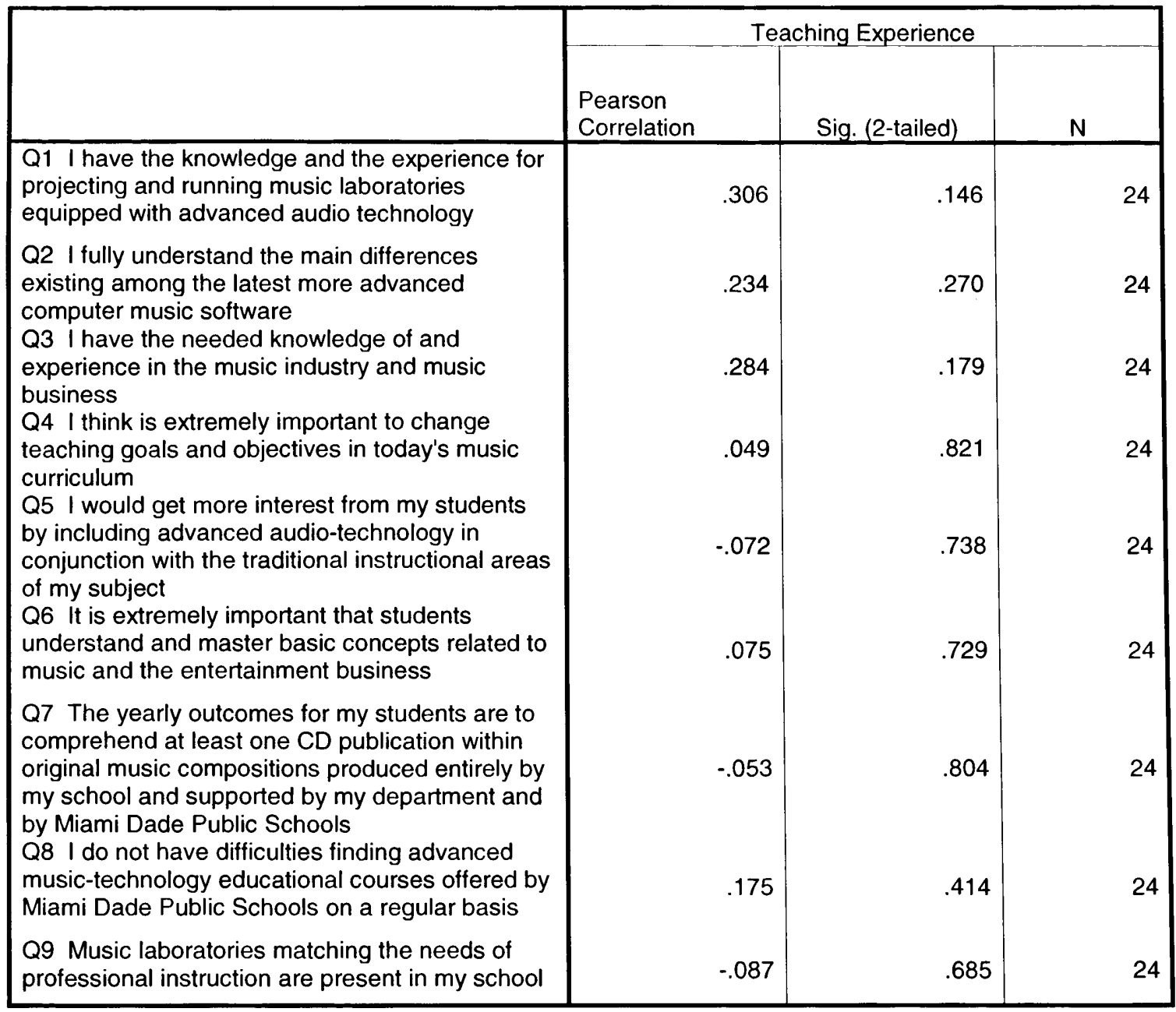

No significant correlation was found between Teaching Experience and responses to the survey questions. 


\begin{tabular}{|c|c|c|c|}
\hline & Indus & y Experience & \\
\hline & $\begin{array}{l}\text { Pearson } \\
\text { Correlation }\end{array}$ & $\begin{array}{l}\text { Sig. }(2- \\
\text { tailed) }\end{array}$ & $\mathrm{N}$ \\
\hline $\begin{array}{l}\text { Q1 I have the knowledge and the experience for } \\
\text { projecting and running music laboratories equipped with } \\
\text { advanced audio technology }\end{array}$ & .397 & .103 & 18 \\
\hline $\begin{array}{l}\text { Q2 I fully understand the main differences existing } \\
\text { among the latest more advanced computer music } \\
\text { software }\end{array}$ & .313 & .206 & 18 \\
\hline $\begin{array}{l}\text { Q3 I have the needed knowledge of and experience in } \\
\text { the music industry and music business }\end{array}$ & .324 & .189 & 18 \\
\hline $\begin{array}{l}\text { Q4 I think is extremely important to change teaching } \\
\text { goals and objectives in today's music curriculum }\end{array}$ & $.550\left(^{\star}\right)$ & .018 & 18 \\
\hline $\begin{array}{l}\text { Q5 I would get more interest from my students by } \\
\text { including advanced audio-technology in conjunction with } \\
\text { the traditional instructional areas of my subject }\end{array}$ & .124 & .624 & 18 \\
\hline $\begin{array}{l}\text { Q6 It is extremely important that students understand } \\
\text { and master basic concepts related to music and the } \\
\text { entertainment business }\end{array}$ & .345 & .161 & 18 \\
\hline $\begin{array}{l}\text { Q7 The yearly outcomes for my students are to } \\
\text { comprehend at least one CD publication within original } \\
\text { music compositions produced entirely by my school and } \\
\text { supported by my department and by Miami Dade Public } \\
\text { Schools }\end{array}$ & .245 & .327 & 18 \\
\hline $\begin{array}{l}\text { Q8 I do not have difficulties finding advanced music- } \\
\text { technology educational courses offered by Miami Dade } \\
\text { Public Schools on a regular basis }\end{array}$ & .358 & .145 & 18 \\
\hline $\begin{array}{l}\text { Q9 Music laboratories matching the needs of } \\
\text { professional instruction are present in my school }\end{array}$ & .237 & .344 & 18 \\
\hline
\end{tabular}

* Correlation is significant at the 0.05 level (2-tailed).

A significant Correlation exists between Industry Experience and views concerning the importance of changing teaching goals and objectives in today's music curriculum (Q.4). 


\begin{tabular}{|c|c|c|c|}
\hline & \multicolumn{3}{|c|}{ Age } \\
\hline & $\begin{array}{l}\text { Pearson } \\
\text { Correlation } \\
\end{array}$ & Sig. (2-tailed) & $\mathrm{N}$ \\
\hline $\begin{array}{l}\text { Q1 I have the knowledge and the experience for projecting } \\
\text { and running music laboratories equipped with advanced } \\
\text { audio technology }\end{array}$ & $.558\left(^{\star \star}\right)$ & .005 & 24 \\
\hline $\begin{array}{l}\text { Q2 I fully understand the main differences existing among } \\
\text { the latest more advanced computer music software }\end{array}$ & $.547\left({ }^{\star \star}\right)$ & .006 & 24 \\
\hline $\begin{array}{l}\text { Q3 I have the needed knowledge of and experience in the } \\
\text { music industry and music business }\end{array}$ & $.523\left(^{\star *}\right)$ & .009 & 24 \\
\hline $\begin{array}{l}\text { Q4 I think is extremely important to change teaching goals } \\
\text { and objectives in today's music curriculum }\end{array}$ & .200 & .350 & 24 \\
\hline $\begin{array}{l}\text { Q5 I would get more interest from my students by including } \\
\text { advanced audio-technology in conjunction with the } \\
\text { traditional instructional areas of my subject }\end{array}$ & -.005 & .982 & 24 \\
\hline $\begin{array}{l}\text { Q6 It is extremely important that students understand and } \\
\text { master basic concepts related to music and the } \\
\text { entertainment business }\end{array}$ & .323 & .123 & 24 \\
\hline $\begin{array}{l}\text { Q7 The yearly outcomes for my students are to } \\
\text { comprehend at least one CD publication within original } \\
\text { music compositions produced entirely by my school and } \\
\text { supported by my department and by Miami Dade Public } \\
\text { Schools }\end{array}$ & .196 & .359 & 24 \\
\hline $\begin{array}{l}\text { Q8 I do not have difficulties finding advanced music- } \\
\text { technology educational courses offered by Miami Dade } \\
\text { Public Schools on a regular basis }\end{array}$ & -.024 & .913 & 24 \\
\hline $\begin{array}{l}\text { Q9 Music laboratories matching the needs of professional } \\
\text { instruction are present in my school }\end{array}$ & .209 & .328 & 24 \\
\hline
\end{tabular}

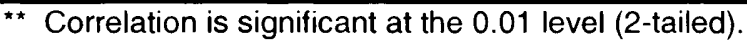

A significant correlation exists between age and responses to statements Q1, Q2, and Q3, suggesting a positive correlation between younger music teachers and their having the knowledge and experience for projecting and running music laboratories equipped with advanced technologies; their understanding the main differences existing among the latest more advanced computer music software; and their knowledge of and experience in the music industry and music business. 


\section{DATA ANALYSIS}

Question \#1 Are music educators acquiring knowledge and becoming familiar with new audio-recording devices and related computer software programs?

According to the results of this study we can conclude that music educators are not acquiring knowledge and becoming familiar with new audio-recording devices and related computer software programs. Thus, the null hypothesis (Hypothesis \#1) is affirmed: Music educators actually teaching at public schools are not delivering adequate instruction about new technologies useful to audio-recording. This hypothesis is substantially supported by the results displayed in Table 8 . On the one hand, the majority of the participants demonstrated some awareness in regard of music notation software like Finale (75\%), perhaps because such software facilitates music theory lectures. On the other hand, almost all of the music instructors involved in this study indicated they knew little about advanced audio-recording computer programs. One hundred percent of them had zero knowledge about advanced audio-recording software like Pro Tools, Nuendo, and Audio Performer, while a minimal percentage of participants had some experience using programs like Cubase Audio VST (4.2\%), Acid (8.3\%), Logic Audio (4.2\%), Garage Band (4.2\%), Mixcraft (4.2\%), and Sibelius (4.2\%). In addition, the results shown in Table 8 can be easily correlated with the first and fifth statements reported in the survey. Of the music teachers surveyed, 58.3\% disagreed with "I fully understand the main differences existing among the latest more advanced computer music software." Of the music teachers surveyed, $45.9 \%$ disagreed with "I have the knowledge and the experience for projecting and running music laboratories equipped with advanced audio-technology." 
Question \#2 Are music educators attending professional seminars and workshops to acquire the necessary knowledge and understanding of new audio technologies?

The data collected in the survey confirm that music educators working in MiamiDade County Public Schools are not attending professional seminars and workshops to acquire the necessary knowledge and understanding of new audio technologies. Again, the null hypothesis (Hypothesis \#2) is affirmed: Music educators are not periodically attending professional workshops and seminars to enhance their competence with music technology and to keep abreast of developments within the music entertainment industry.

In fact, a significant number of participants disagreed (58.3\% vs. $16.7 \%)$ with the statement "I do not have difficulties finding advanced music-technology educational courses offered by Miami-Dade Public Schools on a regular basis." This suggests a lack of opportunities offered by the schools to music instructors who want to enhance their knowledge in this matter.

Question \#3 Are music educators employed in public schools delivering instruction using the latest advanced audio-recording technologies?

Music educators employed in public schools are not delivering instruction using the latest advanced audio-recording technologies. Here, again, the null hypothesis (Hypothesis \#3) is affirmed: Music educators are not using teaching strategies in their classrooms reflecting advanced professional skills.

The supporting evidences come from the data collected in reference to the survey statement "Music laboratories matching the needs of professional instruction are present 
in my school." Of the music teachers surveyed, $66.6 \%$ strongly denied the presence in their school of even the minimum equipment needed for delivering instruction related to any field of electronic music or advanced audio-recording technology.

Question \#4 Are music educators providing their students the necessary specialized knowledge to enhance their entry in the professional entertainment industry?

Data from the survey indicate that the majority of music educators are not preparing their students for successful entry in the professional entertainment industry. Once again, the null hypothesis (Hypothesis \#4) is affirmed: Music educators are not providing their students the necessary specialized knowledge to enhance their entry in the professional entertainment industry. This situation notwithstanding, $66.6 \%$ vs. $12.5 \%$ of the participants agreed with "It is extremely important that students understand and master basic concepts related to music and entertainment business." In addition, $66.7 \%$ vs. $25.0 \%$ of the music educators participating in this study agreed with the statement "I think it is extremely important to change teaching goals and objectives in our today's music curriculum," highlighting a progressive tendency toward more realistic and adequate teaching-learning achievements.

\section{DISCUSSION/CONCLUSION}

The outcomes of this study are definitely unidirectional, bringing up several other possible questions which can become useful starting questions for further research. For instance, why is advanced audio-technology still not a consistent component of the public school music curriculum? Moreover, what is preventing the entry of modern advanced audio-technology in our middle-schools music programs? 
Some possible solutions to the problem follow:

1.) Establishment of mandatory advanced audio-technology and music business courses for sixth-to-eighth grade music teachers.

2.) Yearly mandatory music teachers participation in seminars held by recognized leaders of the entertainment industry.

3.) Administrators should provide the music teachers with adequate support to complete these professional developments.

4.) School administrators should consult with music teachers about technological infrastructure and software purchases.

Whereas technology is largely and successfully used in other academic areas like reading, science, and mathematics, music is a subject still taught applying traditional methods that do not take account of the radical transformation we are experiencing. Keyboards, samplers, mixers, synthesizers are terms very well known to our students. They are ready for the change. Are we? 


\section{LIST OF REFERENCES}

Bartz, D. E. \& Miller, L. K. (1991). 12 Teaching methods to enhance student learning. West Haven, CT: NEA.

Broudy, H. S. (1978). How basic is aesthetic education? Or is ' $r$ the fourth $r$ ?

Paper presented at the annual meeting, Association for Supervision and Curriculum Development (Houston, Texas, March 19-23, 1997, Retrieved August 1, 2010 from http://www.eric.ed.gov/PDFS/ED137310.pdf

Brown, B. L. (1998). How does technology facilitate constructivist learning? ERIC Clearinghouse on Adult, Career, and Vocational Education. Information Series No. 378. Retrieved August 5, 2010 from http://susanlucas.com/it/ail601/crit.html\#tech

Bunch, H. B. (1992). Technology and society. In The New Book of Popular Science (Vol. 6, pp. 2-14). Danbury, CT: Grolier.

Burton, J. K.; Moore, D. M.; \& Magliaro, S. G. (2007). Behaviorism and instructional technology? In Handbook of Research on Educational Communications and Technology, $2^{\text {nd }}$ Edition. D. H. Jonassen (Ed.), 3-36. Mahwah, NJ: Lawrence Erlbaum Associates.

Cain, T. (2004). Theory, technology and the music curriculum. British Journal of Music Education 21 (2), pp. 215-221.

Costa-Giomi, E.; Flowers, P.J.; \& Sasaki,W. (2005). Piano lessons of beginning students who persist or drop out: Teacher behavior, student behavior, and lesson progress. Journal of Research in Music Education, 53 (3), 234-247. Retrieved February 28, 2009 from http://www.ERIC.org. Educational Reproduction Service Center (EJ 739992).

Fink, J. (1992). Recording sound and sight. In The New Book of Popular Science (Vol. 6, pp. 260-269).Danbury, CT: Grolier.

Frasson, C. \& Gauthier, G. (Eds.), (1988). Intelligent tutoring system: At the crossroad of artificial intelligence and education. $\mathrm{NJ}$ : Ablex Publishing Corporation.

Glasgow, R. \& Dale. (n.d.). Study to determine the feasibility of adapting the Carl Orff approach to elementary schools in America. Monmouth: Oregon School of Education. Educational Reproduction Service Center (ED 010804). 
Howard, Priscella, M. (March 1996). Kodaly strategies for instrumental teachers. Music Educators Journal, 82 (5), 27-33. Retrieved March 4, 2009 from http://www.ERIC.org. Educational Reproduction Service Center (EJ528515).

Kashif, M. J. \& Grensberg, G. A. (1996). Everything you'd better know about the record industry. Venice, California: Brooklyn Boy Books.

Keil, C. (1993).Groovology \& the magic of other people's music. Retrieved December 9, 2009 from http://musicgrooves.org/articles/GroovologyAndMagic.pdf.

Kuzmich, J. Jr. (2008) Music gaming and other intro-level learning tools. Retrieved December 9, 2008.

http://www.sbomagazine.com/ME2/dirmod.asp?sid=32D9FE7 1069E4700B723 30CBE40C...

Lipscomb, S.; MacLeod, S.; Mason, K.; Mauricio, D.; Moniz, M.; Muro, D.; Reuter, R.; Richmond, F.; Rudolph, T.; Walls, K.; Watson, S.; \& Whitmore, L. (2006). Technology guide for music educators. Watson, S. (Ed.) pp. 168-207. Boston, MA: Thomson Course Technology.

Lysloff, R.T.A. \& Gay, L.C., Jr. (Eds.) (2003). Music and technoculture. Middletown, CT: Wesley University Press.

Mills, E. \& Therese, C. M., eds., (1973). The Suzuki concept. Berkeley, CA: Diablo.

Malerba, F. (2007, August). Innovation and the dynamic and evolution of industries: Progress and challenges. International Journal of Industrial Organization. 25(4), 675-699.

MacQueen, C. (2005). Pro Tools 7 power! : The comprehensive guide. Boston, MA: Thomson Delmar.

Madsen C. K. \& Madsen C. H., Jr. (1997). Experimental research in music. Chapel Hill, NC: Grantham.

Mark, M. L. (1996). Contemporary music education. $3^{\text {rd }}$ ed. Belmont, California: Schirmer.

Muro, D. (1995) The art of sequencing. Merrick, NY: Electronic Music Products \& Services.

Muro, D. (1994). Statement to Author, November 17, 1994. As cited in Mark, M., L. Contemporary music education. $3^{\text {rd }}$ ed. Belmont, CA Shirmer, pp.195-196. 
Schmidt, M. (2005). Preservice string teachers' lesson-planning process: An exploratory Study. Journal of Research in Music Education, 53 (1), 6-25.

Retrieved February 25,2009 from http:// www.ERIC.org. Educational Reproduction Service Center (EJ714369).

Shelemay, K. K. (2000). Soundscapes: Exploring music in a changing world. New York City: M. Ochs.

Shemel, S. \& Krasilovsky, W. M. (1990). This business of music. New York City: Billboard Books.

Shemel S. \& W., Krasilovsky, M. (1989). More about this business of music. $4^{\text {th }}$ ed. New York City: Zhito.

Spring, J. (2002). American education. $10^{\text {th }}$ ed. New York City: McGraw-Hill.

Steiniz, T. (1988).Teaching music in rhythmic lessons: Theory and practice of the Delacroze method. Tel Aviv: OR-TAV.

Strommen, E. F. \& Lincoln, B. (2007). Constructivism, technology and the future of classroom learning. Education and Urban Society. 24(4), 466-76. 


\section{APPENDIX}

\section{SURVEY}

\section{SECTION I: DEMOGRAPHIC DATA}

Where is your work location?

What grade level do you teach?

Please check with an " $x$ " the following areas:

Your teaching area:

General Music ..... Vocal / Choral Music ..... Instrumental Music ..... Other .....

\section{Degrees Held}

Bachelor's ..... Master's ..... Doctorate .....

\section{Gender}

Male ..... Female .....

\section{Teaching Experience}

1-3 years ..... 4-10 years ..... 11-20 years ..... 21-30 years ..... More than 30 years .....

\section{Music/Entertainment Industry Experience}

1-3 years ..... 4-10 years .... 11-20 years .... 21-30 years ..... More than 30 years .....

\section{Use of Computer Music-Software}

Protools (any version) ..... Cubase VST Audio (any version) ..... Nuendo (any version) ..... Logic Audio (any version) ..... Audio Performer (any version) ..... Acid (any version) ..... Finale (any version) .....

\section{Publications}

Songs ..... CDs (Published by Major Recording Labels) ..... Articles ..... Books .....

\section{Age}


SECTION II: SURVEY QUESTIONS

\section{Please check with an " $x$ " the selected answer}

\begin{tabular}{|c|c|c|c|c|c|}
\hline $\begin{array}{l}\text { Please respond to the items below to } \\
\text { register the strength of your } \\
\text { agreement or disagreement. }\end{array}$ & $\begin{array}{l}1- \\
\text { strongly } \\
\text { disagree }\end{array}$ & $\begin{array}{l}2- \\
\text { disagree }\end{array}$ & $\begin{array}{l}3- \\
\text { neutral }\end{array}$ & $\begin{array}{l}4- \\
\text { agree }\end{array}$ & $\begin{array}{l}5- \\
\text { strongly } \\
\text { agree }\end{array}$ \\
\hline $\begin{array}{l}\text { I have the knowledge and the experience for } \\
\text { projecting and running music laboratories } \\
\text { equipped with advanced audio-technology. }\end{array}$ & & & & & \\
\hline $\begin{array}{l}\text { I fully understand the main differences } \\
\text { existing among the latest more advanced } \\
\text { computer music software. }\end{array}$ & & & & & \\
\hline $\begin{array}{l}\text { I have the needed knowledge and } \\
\text { experience in regard of music industry and } \\
\text { music business. }\end{array}$ & & & & & \\
\hline $\begin{array}{l}\text { I think it is extremely important to change } \\
\text { teaching goals and objectives in our today's } \\
\text { music curriculums. }\end{array}$ & & & & & \\
\hline $\begin{array}{l}\text { I would get more consideration from my } \\
\text { students delivering advanced audio- } \\
\text { technology culture in conjunction with the } \\
\text { traditional instructional areas of my subject. }\end{array}$ & & & & & \\
\hline $\begin{array}{l}\text { It is extremely important that students } \\
\text { understand and master basic concepts } \\
\text { related to music and entertainment business }\end{array}$ & & & & & \\
\hline $\begin{array}{l}\text { The yearly outcomes of my students } \\
\text { comprehend at least one CD publication } \\
\text { within original music compositions } \\
\text { produced entirely by my school and } \\
\text { supported by my department and by Miami } \\
\text { Dade Public School. }\end{array}$ & & & & & \\
\hline $\begin{array}{l}\text { I do not have difficulties finding advanced } \\
\text { music-technology educational courses } \\
\text { offered by Miami Dade Public Schools on a } \\
\text { regular basis. }\end{array}$ & & & & & \\
\hline $\begin{array}{l}\text { Music laboratories matching the needs of } \\
\text { professional instruction are present in my } \\
\text { school.. }\end{array}$ & & & & & \\
\hline
\end{tabular}

